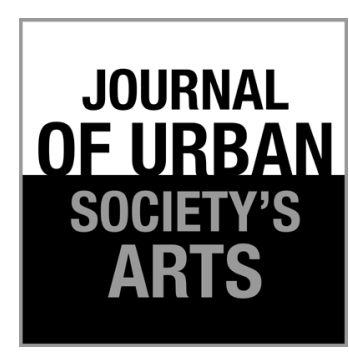

Volume 7 Nomor 1, April 2020: 30-42

\section{Women Emancipation and Empowerment in The Incredibles 1 and 2}

\author{
Larisa Indriani Putri \& Lucia Lusi Ani Handayani \\ Program Studi Inggris, Fakultas Ilmu Pengetahuan Budaya \\ Universitas Indonesia \\ Kampus UI Depok, Jawa Barat 16424 \\ Email: lucia.lusi@ui.ac.id; HP.: +628159904734
}

\begin{abstract}
Movies represent women differently from men. Some try to raise women's dignity, and some still impose traditional values on them. This paper studies the representation of the characters of female superhero in The Incredibles 1 and 2 which seem to support women's emancipation. However, there are some ideas conveyed through the miseen-scéne which still indicate that the movie series do not fully emancipate women. The Incredibles 1 and 2 movie series have been chosen as the object of the study for their typical characteristics when female superhero plays the role. The purpose of this paper is to examine how women are represented through visuals and character roles in The Incredibles 1 and 2 . The movies were analyzed through a critical discourse approach. The analysis focused on the language beyond sentences and aspects outside the language, such as power relation, social context, and ideology. The result of the analysis shows that the female character in the movies still upholds traditional values, such as male domination, revealing that these movies are not emancipatory for women. Moreover, women are still degraded and objectified through their body. Therefore, these movies can be seen as a form of pseudo-empowerment, where something is seen as empowering but actually it is not.
\end{abstract}

Keywords: women representation; incredible film; subordination; empowerment

\begin{abstract}
ABSTRAK
Emansipasi dan Pemberdayaan Perempuan dalam Film Incredibles 1 dan 2. Film menggambarkan perempuan dan laki-laki dengan cara yang berbeda. Sebagian mencoba untuk menaikkan derajat perempuan, dan sebagian masih menyajikan nilainilai tradisional. Artikel ini meneliti representasi karakter perempuan utama pada film The Incredibles 1 dan 2 yang terlihat mendukung emansipasi perempuan melalui karakter superhero. Namun, terdapat gagasan yang menunjukkan bahwa kedua film ini tidak sepenuhnya mengemansipasi perempuan. Artikel ini bertujuan untuk meneliti bagaimana perempuan digambarkan melalui visual dan peran pada setiap karakter di The Incredibles 1 dan 2. Kedua film ini dianalisa menggunakan pendekatan analisis wacana. Analisis dilakukan pada tingkat bahasa yang digunakan yang tidak terbatas pada kalimat dan aspek-aspek di luar bahasa, seperti hubungan kekuasaan, konteks social, dan ideologi. Hasil analisis menunjukkan bahwa karakter perempuan pada kedua film ini masih menjunjung tinggi nilai-nilai tradisional, seperti dominasi oleh laki-laki. Hal ini membuktikan bahwa film-film ini tidak merepresentasikan kebebasan pada perempuan. Lebih lagi, melalui tubuhnya, perempuan masih terlihat direndahkan dan dijadikan sebagai objek. Oleh karena itu, dapat disimpulkan bahwa film-film ini merupakan suatu pseudo-empowerment, yaitu ketika sesuatu terlihat seperti memberikan kebebasan namun dalam kenyataanya tidak sama sekali.
\end{abstract}

Kata kunci: representasi perempuan; film incredible; subordinasi; pemberdayaan 


\section{Introduction}

From early childhood, we all have known that most animated movies are dominated by male superheroes as the main characters. However, in the past few years, superhero-themed movies have made women as their main characters. According to Five Thirty Eight research (2014), earlier, there were around 24-29 percent of female characters in the DC Universe and Marvel Universe, and recent research has found that there are around 30 percent of female characters. The state of women representation in superhero movies has become a hot topic of discussion after the feminists.

Therefore, The Incredibles 1 dan 2 are chosen as the corpuses of this paper because these movies seem to dignify women by making a woman to be one of the main characters. The Incredibles 1 tells about a superhero family, the Incredibles. The Incredibles are forced to live as a normal family, not as a superhero family anymore because government has determined superhero as illegal. Nonetheless, Mr. Incredible as the head of the family is struggling in his office so that he is back in his business as a superhero with secret assignment. Sadly, he is trapped in the enemy's plan. This causes Elastigirl to help Mr. Incredible. The Incredibles 2 tells about the changing roles of Elastigirl and Mr. Incredible within the family. Elastigirl is needed to save the world and to prove that superhero is worthy to be legal, while $\mathrm{Mr}$. Incredible stays at home to take care of children. However, at the end of the story, Elastigirl is being rescued by his husband as she is trapped in a chaotic situation made by the enemy.

Study on feminism has been around for decades. However, the increasing progress of feminists started from the women's liberation movement in the 1960s. Although superhero characters were still predominantly men in the $20^{\text {th }}$ century, at least, comic creators were brave enough to depict female superheroes. They tried to promote the capability of both genders in saving the world. Therefore, they offered women emancipation in the superhero domain, and it seemed that women were being empowered. Women empowerment has been defined as the emancipation of women in every aspects of life, which means that women are given freedom in choosing anything and there is no oppression anymore (Kulkarni, 2017). Likewise, Wright (1993) has mentioned that emancipation is promoting gender equality in both welfare and power, meaning that women emancipation is to banish the gender inequality in every aspects of life.

In the meantime, Marxist (in Mirkin, 2009) has said that men are the ones that govern power in institutional areas in patriarchal system. And, this power has shaped people's ideology, philosophy, art, and religion in order to fulfill their needs. Male power is often seen as a conspiring act that is viewed as negative, and women are seen as the ones that are targeted with men's negative acts and can be perceived as the oppressed class. Based on traditional cultures in most countries, men are charged and mostly chosen to be the leader in every aspect, such as at government, office, and even home. The concept of patriarchy and sexual domination, as articulated by Simone de Beauvoir (in Mirkin, 2009) is the most powerful, rigid, and abiding form of segregation. Moreover, Mirkin says that women are passive and unaware victims of patriarchy. Since patriarchy vividly appears in culture, women inevitably accept it. Additionally, Adrienne Rich (in Mirkin, 2009) says that the power of fathers pervades everything where we always need male's approval.

Several studies have discussed the representation of women in Wonder Woman movie, and superwoman in The Incredibles 1 and 2 movies. Those studies have resulted in various women portrayal in movies, such as the negative and positive depiction of women through characters, and the controversies of female representation that emerge from women character. Dipaolo's study (2013) has concluded that Wonder Woman movie has the perfect role model of female superhero because the female character, Diana, could change the world by improving women's lives through her positive thoughts. However, Carolyn (2014) disagrees to this conclusion by arguing that Diana, as a female superhero, does not portray women properly. This is because her superpower crosses the gender line which is shown by the adherence of male elements to her character. Being a superhero that fights humans or even monsters makes her less 
feminine. In addition, Diana is sexualized through her "sexy" appearance by her wearing of mini skirt and strapless top.

Ryan (2014) has analyzed the representation of motherhood in American films in the 1970s in order to understand the wider construction of gendered cultural meanings. Another study conducted by Majhi (2017) discusses the "Paradox of Gender Equality in Hollywood Superhero Movies". He concludes that all female superheroes, which are viewed as female emancipation, are actually victimized by patriarchal society representing masculinity. We can see that researchers have already found the negative aspects of those movies that seem empowering to women. Moreover, those studies largely focus on how female superheroes are portrayed, and whether the issues of women emancipation are raised implicitly in these female superhero movies. However, none of them have analyzed the specific facts behind the female emancipation and empowerment that is portrayed in The Incredibles 1 and 2 movies through visuals and actions of female characters. Articles on The Incredibles 2 usually discuss the genuine aspects of women empowerment and switch into gender roles. For example, the article written by Tailor (2018) discusses the equality in a family that leads to women empowerment. Also, according to Burnett (2018), The Incredibles 2's main characters, Elastigirl and Mr. Incredible, break their own gender roles.

This paper will further examine the representation of women in these movies through a more detailed analysis of each female character, from the way she is sexualized and portrayed as dependent and having an unequal power relationship. Burnett emphasizes that gender and power relationship is related to the inequality and power imbalance between men and women. The movie seems to offer space for women as superheroes as well as mothers. Therefore, this paper focuses on how the female representation is still problematic in The Incredibles 1 and 2. However, none has asked how the women empowerment is represented through the characters and actions in the movie The Incredibles and its sequel. The fact is that male domination in most movies still exists. Women are still objectified and sexualized through their appearance and actions. This study tries to unmask the message under the idea of women empowerment. It also tries to identify the existence of women empowerment and emancipation in the movie industry. Empowerment is one of the alternatives to create gender equality in this world.

There are some concepts that are used in analyzing The Incredibles 1 and 2, which are empowerment, emancipation, the second sex, male gaze, and gender role and power. First, Rowlands (1995) argues that empowerment is more than decision-making. This means that people should go through a process to be able to make decisionmaking. In practice, it means that people's personal development involves movement from insight to action, and self-improvement from bad to good. Empowerment is also an activity that challenges the existing domination and inequality. People need changes in order to feel certain in their own ability to identify themselves and know their true needs, as housewives or workers. In terms of feminism, oppression occurs on both men and women. Women's empowerment is the ability of people to subvert stereotypes, social constructions, or values, and norms that have restricted them. In so doing, they can have choices in their lives that encourage them to become an individual with a purpose, such as when women do not follow the body image of slimness for women (Kabeer, 2002). Women's empowerment needs persons' freedom and selfconfidence (Karolak, n.d.). It allows women to have equality treatment in life by having the same opportunities and the same power as men (T.M. Fapohunda, 2009). Women's emancipation is another step in the effort to achieve women's liberation through actions and strategies in their lives until they can change and develop themselves into truly having freedom (Ruane $\&$ Todd, 2005).

The second sex is another concept to be used for analysis. According to de Beauvoir, the second sex refers to women that have limited roles, while men have unlimited roles (1949). Women are very often seen as inferior to men. For example, the men often have higher positions or strata than women. Another case is when men are regarded as tougher than women, which happens frequently in superhero movies. 
The other concept used in this paper is gaze theory. Women are represented through the lens of male desire to attract men, thus the real "woman" is wiped away (Erens 1990, Johnston 1999, Cowie 200). This is related to Laura Mulvey's statement on 'the male gaze'. In film, women are often represented to fulfill male desire, hoping to grasp male attention (Mulvey, 1975). Based on the concept of scopophilia, which is pleasure in looking, she argues that film gives the audience "an illusion of looking in on a private world." Furthermore, regardless of what women do, they are still sexualized and objectified in movies. Women's objectification is obviously caused by men, since "the male figure cannot bear the burden of sexual objectification" (Mulvey 1975). Mulvey discusses how women are objectified by men in media as a product of the "male gaze" (as cited in Freeman, 2018). She says that women have two roles in film; women gain pleasure as the object of desire that actually hurts them, or are identified by men that are active viewers as transsexual women. Freeman believes that the male gaze and sexual objectification are interchangeable because sexual objectification refers to a state of pleasure resulted from looking at the person's body parts and considering the person as an object (2018). Mulvey (1975) elaborates more by outlining three types of looking; how the camera looks, how the audiences watch the movie, and how the characters look and see each other (as cited in Kinnunen, 2016). Mulvey also states that women have two functions in a movie, namely as an object of the movie that can arouse sexual desire, and as an object of spectators that can arouse sexual desire too.

The last two concepts related to the topic of this paper are gender roles and gender power relation. Gender roles are the shared beliefs that are built by society for individual man and woman, which are characterized by their sex and differentiated in their habits, behaviors, and tasks (Eagle, 2009). Gender power relation was first discovered and discussed by Robert Conell and used in an article discussing gender power in HIV patients (Wingwood \& DiClémente, 2000). According to Agrawal (1997)(as cited in MacPherson 2014), gender power relation shapes and attributes men and women different habits, skills, capabilities, and desires. Similarly, Sen Östlin (2007)(as cited in MacPherson 2014) mentions that gendered power relations control and regulate people's beliefs, way of life, and understanding. Meanwhile, Tolhurst and Leach (2012) (as cited in MacPherson 2014) have said that gender power relation is usually related to hierarchy between two gender, "a woman is not simply 'even more disadvantaged' because she is also disabled. Rather gender intersects with these multiple social divisions and inequalities to create specific personalities in relation to power". The unequal treatment is usually faced by women because men, in traditional culture, have higher and stronger power than women. It still happens in modern society at some places where men are more trusted to be leaders than women, either in households, workspaces, or even communities.

\section{Women in Subordination}

The movies seem to represent emancipation for women by creating a female superhero, i.e. Elastigirl. Being a superhero means that Elastigirl is not dependent on men. She should have equal power as men. When analyzed further, however, the female superhero does not receive equal treatment from the moviemakers, that is Mr. Incredible seems superior to his wife, Elastigirl.

The characters' names in The Incredibles 1 and 2 seem to symbolize their abilities and gender roles. Elastigirl is given the power of flexibility, which means that her body can be stretched, expanded, and deformed, but she is not given strength like Mr. Incredible. Mr. Incredible, as portrayed by his name, is a very extraordinary superhero with amazingly good strength and ability. He has a super-human and invulnerable power, where he can lift, hold, pull and push any heavy things without being hurt, while Elastigirl is not given a superhuman power. She may fight with any opponent by punching him, but she does not truly have superpowers because she cannot lift up heavy things like Mr. Incredible can, even though she is also a superhero. Mostly, she uses her elasticity to perform her job as a superhero. From their superpowers, it can be seen that division of the superpowers 
is not equal. Elastic girl and Mr. Incredible have superpower that is somehow in line with gender construction. This is kind of an unequal power division between genders.

The name of the female superhero, Elastigirl, suggests the idea that women are expected to be flexible in everything. In daily life, women are expected to multitask, such as being a mother, wife, and worker at the same time. She is expected to do all things, ranging from domestic chores to work career. Meanwhile, Mr. Incredible's name strengthens the affirmation that men are always incredible or good at doing anything, whether a job or housework. However, it does not conform to the facts of the character himself because he often fails to do things. At first he always tries to do his job as superhero by helping and saving people, but afterwards he fails and destroys other things. Thus, his name does not reflect his actions. Meanwhile, Elastigirl's name truly reflects her actions because she does the best in her job as a superhero and as a mother. In short, it asserts implicitly that women should truly be able to do good in everything, while men do not have to be.

Male domination is still apparent in The Incredibles 1 and 2, which suggests that these movies do not truly promote women's empowerment and emancipation. The main female character in The Incredibles 1 and 2 is Elastigirl. In the first movie, at the beginning, superheroes are considered as destructions for the city that make them become illegal. Therefore, Elastigirl does not adopt her identity as a superhero and uses her real name, Helen. At that time, it is obvious that she represents an actual mother and is not empowered or even emancipated at all. She stays at home, taking care

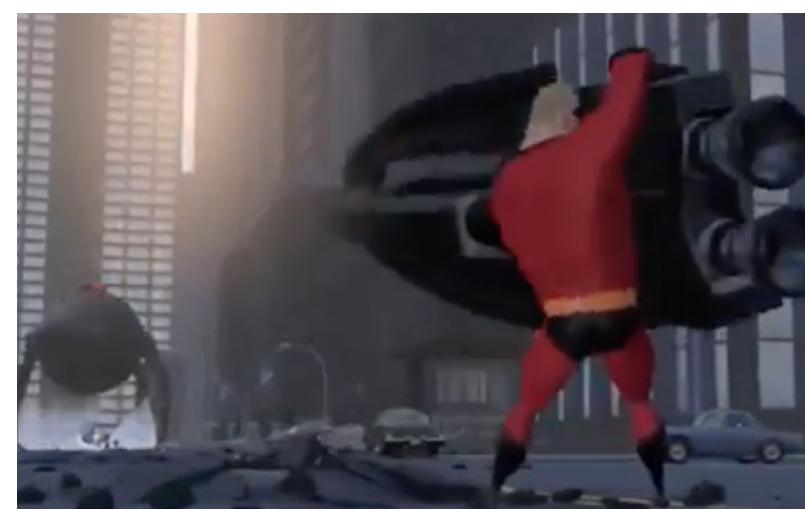

Figure 1. Mr. Incredible is lifting up robot's hand. of the children, while Mr. Incredible works at the office. At the ending, however, she uses her power as Elastigirl to help her husband, Mr. Incredible who is in trouble. At the end of the first movie, it seems that women are emancipated and empowered because Elastigirl is doing her job as a superhero and showing her independency. She is able to drive an airplane by herself and fight all the security officers in the villain's base. However, at the end, she does not truly help her husband. Instead, she only finds that he has already been freed because the one who helps Mr. Incredible is another character. Moreover, when they are both fighting against the villain's guards, Mr. Incredible always takes care of the harder parts. For example, when they fight a huge robot, Mr. Incredible lifts up one of the robot's huge arm (see Figure 1) that has already been detached from its body and he is attacking the robot with its arm without any hardship.

When Elastigirl is helping her husband, she needs to lift up the aqueduct's cover and throw it towards the enemy (see Figure 2). However, she has difficulty in lifting it up, showed by the inconvenient expressions and body gestures. She feels that it is so heavy that even though she can still lift it up, she does so with much effort. She has a much easier job, yet she still has difficulties in performing that part. This scene implies that a woman, even though she is a superwoman, is still not strong enough. In other words, men are still stronger than women. Mr. Incredible as the husband still dominates the gender roles, and still regards his wife as the second sex because she cannot do tough jobs. Although Elastigirl is a superhero, she still gets the easier parts in fighting with the enemies compared to her husband. It happens because she is not given

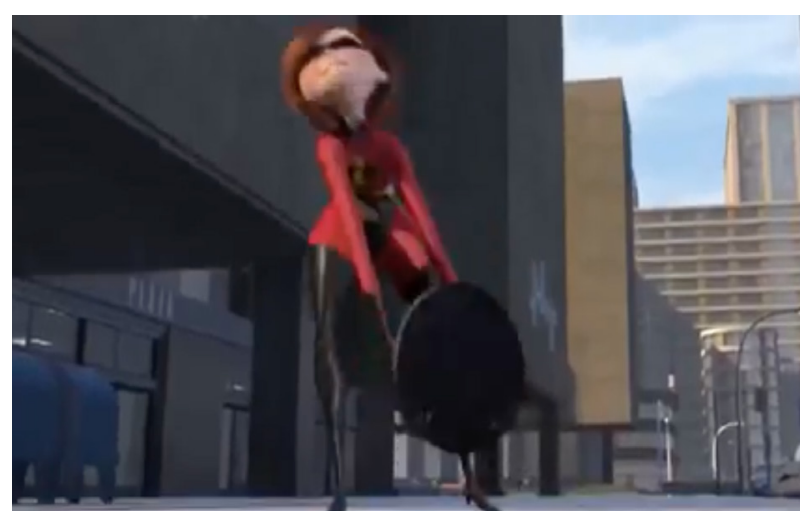

Figure 2. Elastigirl is lifting up the aqueduct's lid. 
physical power and strength like Mr. Incredible. The superpower division can reveal the gender roles where man is stronger than any woman. Also, it shows the inferiority of women who have fewer roles in doing the superhero job because the most important thing in becoming superhero is physical power. Therefore, Mr. Incredible, as a man, has the dominant role because he has the physical power while Elastigirl, as a woman, only needs to assist him because she has less responsibility.

Although Elastigirl in The Incredibles 2 has a great role as one of the main superheroes who save the city, the movie still does not represent genuine empowerment of women. At the beginning, when the Incredible's family try to help the city, $\mathrm{Mr}$. Incredible is holding a running giant drill away from the street, saying "I'm going to keep it away from the building". In the meantime, Elastigirl is only stopping cars on the highways to prevent car crash by utilizing her flexibility, stretching her hand to reach the cars. She exclaims, "Stop, every body stop. "After that, she still needs her husband's help in doing her job to help saving the city: "Bob, help me with the pillar." At the end of the story, when Elastigirl is trapped by the villain, Mr. Incredible comes to help his wife. We can see this in the phone conversation between the villain and $\mathrm{Mr}$. Incredible: "Elastigirl is in trouble." says the villain, "What? What happened to her?" Mr. Incredible answers, "Sorry to tell you on the phone, meet me on the ship of Devtech (Devtech's cruise)." the villain urges Mr. Incredible, "Ship of Devtech. I'll be there for 15 minutes. "In this scene, we can see that when Elastigirl is in trouble, the last choice and the only one who can save her is her husband. We can see from these scenes that even though the female superhero seems to empower women, she actually does ruin the idea of 'empowerment'. The woman in this movie is supposed to be strong, but she still needs a man to help her. So, we can see that women are still undermined by society, especially by men.

In The Incredibles 1, Mr. Incredible also regards his wife as weaker than him. He asks her to do nothing while he is fighting with hazardous enemy, even though he knows that she is also a superhero. As in this clip, Bob says "Wait here and stay hidden.
I'm going in. "Helen answers "While what? I watch helplessly from the sidelines? I don't think so.". He says this because he loves his wife and does not want anything bad to happen to her. However, it also implies that he does not want her to fight with a dangerous foe because he thinks that it is a highrisk job for Elastigirl. The possibility for Elastigirl to be in trouble is very significant. He does not trust her ability as a superhero to fight the enemy, and he underestimates her strength. Therefore, we can see that no matter what background a woman has, she is still treated as weak. No matter what happens, men still think that they are stronger than any women.

Additionally, there is a contrasting idea in what the female character shows and how it is represented in the movie. She says: "While what? I watch helplessly from the sidelines? I don't think so." She implies that she is actually showing an uprising, as she cannot accept the fact that her husband is undermining her ability as a woman. She attempts to prove that she can do anything that her husband can. Hence, she shows agency and independence. She uses her voice to exercise her agency by speaking aloud about what she is objecting to (Trites, 1997). She has a desire to be equal to Mr. Incredible. Here, she actually tries to empower herself. On the other hand, the movie tries to degrade women by giving an unequal superpower to Elastigirl in that Mr. Incredible is still more powerful than Elastigirl.

The superiority of men over women can still be seen in the same scene when Mr. Incredible asks his wife to stay in their car and protect their children. Mr. Incredible says "I'm asking you to wait with the kids.", Elastigirl replies "And I am telling you not a chance. You are my husband. I am with you for better or worse." and Mr. Incredible responds "I have to do this alone." While saying this, Mr. Incredible places a bold emphasis that he needs his wife to follow what he asks. He does not involve his wife in his tasks, and he does not want to be bothered by her presence. He knows the boundary between male and female tasks; men do office tasks, while women do home tasks. Thus, we can see the traditional value that women should follow anything that their husband demand 
because the prevalence of male domination and female subordination is very obvious.

Patriarchal values also appear when $\mathrm{Mr}$. Incredible loses his job both at the company and as a superhero. He is confused about what he should do to fend for his family. He and his wife conclude that one of them should get a job to support their family. So, Elastigirl says "Maybe it's my turn in the private sector and you take...". Then, Mr. Incredible cuts her words by saying "No, I'm doing this." Here, we can see the patriarchal values that the one who must fend for the family is the man, while the woman should stay at home, taking care of the house and children. Another conversation between Elastigirl and Mr. Incredible that characterizes male superiority occurs in the beginning of The Incredibles 1:

(1) THIEF: Hey, look--

(2) MR. INCREDIBLE: Elastigirl.

(3) ELASTIGIRL: Mr. Incredible.

(4) MR. INCREDIBLE: No, it's all right. I've got him.

(5) ELASTIGIRL: Sure, you've got him. I just took him out for you.

(6) MR. INCREDIBLE: Sure, you took him out. His attention was on me.

(7) ELASTIGIRL: A fact I exploited to do my job.

(8) MR. INCREDIBLE: My job, you mean.

(9) ELASTIGIRL: A simple thank you will suffice.

(10) MR. INCREDIBLE: Thanks, but I don't need any help.

(11) ELASTIGIRL: Whatever happened to "ladies first"?

(12) MR. INCREDIBLE: Well, whatever happened to equal treatment?

(13) THIEF: Hey, look, the lady got me first.

(14) ELASTIGIRL: Well, we could share, you know.

(15) MR. INCREDIBLE: I work alone.

(16) ELASTIGIRL: Well, I think you need to be more...flexible.

(17) MR. INCREDIBLE: Are you doing anything later?

(18) ELASTIGIRL: I have a previous engagement.

(19) MR. INCREDIBLE: [whistles]

This conversation is their debate to show who is superior between Mr. Incredible and Elastigirl.
They are debating on who caught the thief first, and both of them do not want to give in, especially $\mathrm{Mr}$. Incredible. In fact, Elastigirl is the one who truly caught the thief first. However, Mr. Incredible is aware of his position as a man, and of traditional roles in gender in which the male is superior to the female. Therefore, he has high prestige to lose by yielding to a woman. For example, after debating for a while, Mr. Incredible says "Thanks, but I don't need any help", then Elastigirl answers "Whatever happened to "ladies first"?", and Mr. Incredible replies "Well, whatever happened to equal treatment?" Here, Mr. Incredible thinks that he is more powerful as man than any woman. He feels stronger and superior, and he can do anything by himself without a woman's help in order to keep his position as a male. He feels that his masculinity is being threatened by a woman's presence in his job. However, Elastigirl's response still tries to make Mr. Incredible give in by appealing to the traditional roles of gender. Elastigirl still makes an effort to show her power, but she uses strata in gender to win the debate and to be considered more powerful and superior. After that, Mr. Incredible responds by using the term equal treatment to retain his dignity. From this conversation, we can see that a man cannot let himself be seen as weaker than a woman. His prestige is too high to concede his apparent ability in power.

Additionally, at the beginning of The Incredibles 2, there is a boy called Tony Rydinger. He is interested in Mr. Incredible's daughter, Violet. However, the moment is destroyed when he sees Violet helping her parents in saving the city and wearing superhero suit. He is very shocked when he knows that it is his crush at school. This makes him run off from Violet. Here, we can see that he cannot accept the fact that his crush is a superhero. By running off from Violet, it symbolizes that he is afraid of her and unable to accept that a girl can be a superhero while he as a boy is only an ordinary human. This is supported by him saying "I wish I could forget I ever saw her in that suit." In other words, he cannot accept the fact that she is much stronger than him. It portrays his perceptions about girls that girls should not be that strong. $\mathrm{He}$ feels that his superiority as a boy is threatened by 
this revelation. It implies the unequal treatment between men and women that dictates how women should not be stronger than men. From this excerpt, we could see that society has shaped people's ideas, thought, and perception about men and women.

Gender roles in these movies can be explained with de Beauvoir's (1949) concepts second sex. She states that men have more roles than women, which makes the inferiority of women very apparent (de Beauvoir, 1949). Although in this modern era, where there is no conspicuous action against women or even to humiliate women, there is still a conventional idea about the subordination of women that manifests in society. There are still patriarchal values where men are superior to women.

To conclude from The Incredibles 1 and 2, Mr. Incredible and Elastigirl superpower division has already determined the gender roles where only man can have the super-strength, while woman is only given a flexible body. This unequal superpower division between genders makes it obvious that men are still treated as superior than women. Moreover, Mr. Incredible still underestimates the ability of his wife to be a superhero. He still thinks that men are stronger than women, although his wife is a superhero. Men feel that they have a responsibility to protect their wives. These movies still implicitly represent a conventional idea about men and women's roles. Men have more roles that are more complicated or even harder roles than women. Not only do the movies perpetuate the regressive beliefs of the male character as made by the moviemakers, they also promote the patriarchal values that lead to the subordination of women. Even though this is the modern era when women have already been free and recognized, there are still some traditional views that are unconsciously implemented in our lives. This superiority of men leads us to R.W. Conell (1995) Concept of Hegemonic Masculinity, where people unconsciously make superior characters of men to be standards, such as tough, competitive, dominant, and aggressive behavior. The demand of men to follow that hegemonic masculinity makes women seem inferior. Therefore, this degradation of women in these movies has it is own cause from the hegemonic masculinity.

\section{Women Being Sexually Objectified}

Female superheroes are not only considered for their strength, but also for their attractiveness. This is evident in the case of Elastigirl, who is sexualized through her attractive body shape and movement, as well as the way the camera angle emphasizes her physique. In doing so, the movie series seems to represent women as sexual objects, where they are regarded as desirable objects to please men.

In the movie, although Elastigirl can fight any muscular man, she does not have a muscular figure. She is portrayed as having short reddish brown hair and a slender body. She represents a certain body image which is standard for women, i.e. small waist, big breasts and bottoms, thick thighs, small legs and hands. She wears a skintight black onepiece cloth that accentuates her body shape (see Figure 3). This kind of body image has already been popular in media and is promoted by some public figures. The representation of women in media shapes the images and concept of female beauty standards especially the idea that "thin is beauty" (Castillo, n.d.). She might have a larger rear, breasts, and thighs, but she actually reflects the idea of thin body. Her waist, hands, and legs are very thin. Such body shape is very desirable. At the same time, however, she has good and curvaceous shapes in certain body parts. This attractive body shape creates a desire in men. Big breasts and bottoms may arouse men's sexual desire. Elastigirl attractiveness can also be seen through her clothes.

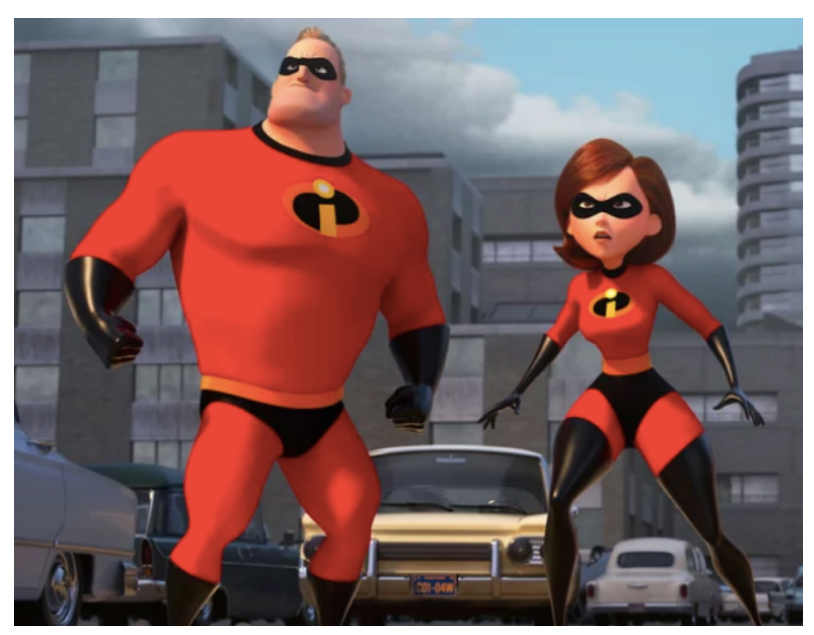

Figure 3. Mr. Incredible and Elastigirl in their superhero costumes. 
Her superhero costume is in a combination of red and black. Wearing red clothes makes women more attractive to men because women in red often carry sexual meaning (Pazda, 2012). In the article of UCL (2019), red is often identified as prostitute. Elastigirl puts black-colored-costume on her body emphasizing particular body parts, namely arms, legs, and the V-shape highlighting her groin, which is improper. Therefore, we can see that she is sexualized from her clothes color, shape, and design.

Although Mr. Incredible also wears similar tight clothes which emphasizes particular body parts, it has a different meaning. A man wears a tight outfit in order to show his muscles as well as his power. A man with a good amount of muscle symbolizes masculinity because this is associated with strength, domination, and competition (Neagu, 2015).

Furthermore, some camera angles focus on Elastigirl's particular body parts which are exposed deliberately. The most obvious exposure of Elastigirl's body part is her buttocks. When she is riding a motorcycle in one of the scenes, the camera is shooting her body from the back, then to the side before it moves to her face. Such shooting techniques expose her body shape clearly. The camera shoots from the back to draw attention to her most attractive body feature, which is her big buttocks. Moreover, her position in riding the motorcycle by leaning forward can show her perfect body shapes, especially her backsides (see Figure 4). There are some other scenes where the camera shoots her from her back first before showing her face. There are two angles in different scenes where the mirror reflects her back, while the camera shoots her front body parts. At her rear, her buttocks are exaggerated, and at her front body, her breasts and thighs are being exaggerated as well. Also, her hips are exaggerated to make her body look sexier. Mr. Incredible is also exaggerated, but it focuses on his chest and muscular arms. Here, man is exaggerated in order to show his power through his physique, rather than his sexuality or sexy body parts. The camera focus on Elastigirl's particular body parts relates to Laura Mulvey's male gaze concept. The male gaze happens in that men find pleasure in seeing women's bodies. So, according to this concept, Elastigirl is treated as an object not as a person. It is because the camera angle focuses more on her body rather than her identity.

There is a contrasting idea between the character itself and how the camera represents the character. Here, Elastigirl is trying to empower herself, to put herself as equal to men by becoming a superhero and doing a though job of fighting enemies like what Mr. Incredible does. However, the camera angle accentuates her in a different manner. It emphasizes some of her body parts, which are usually regarded as sexy. Her personhood is obscured by how the camera angle is fixated on certain features that she has. There is an ambiguity here. On one hand, she tries to empower herself, yet the camera angle disempowers her. This can be seen as an objectification of woman's body from a particular viewpoint. On the other hand, her characteristics which are her personality, agency, and subjectivity are strong. Thus, it can be said that she is an independent and fully defined character instead of a mere object.

Sexual objectification cannot only be seen physically, but it can also be seen from the spoken words or statements of the characters. Elastigirl is sexually objectified by Mr. Incredible's utterances
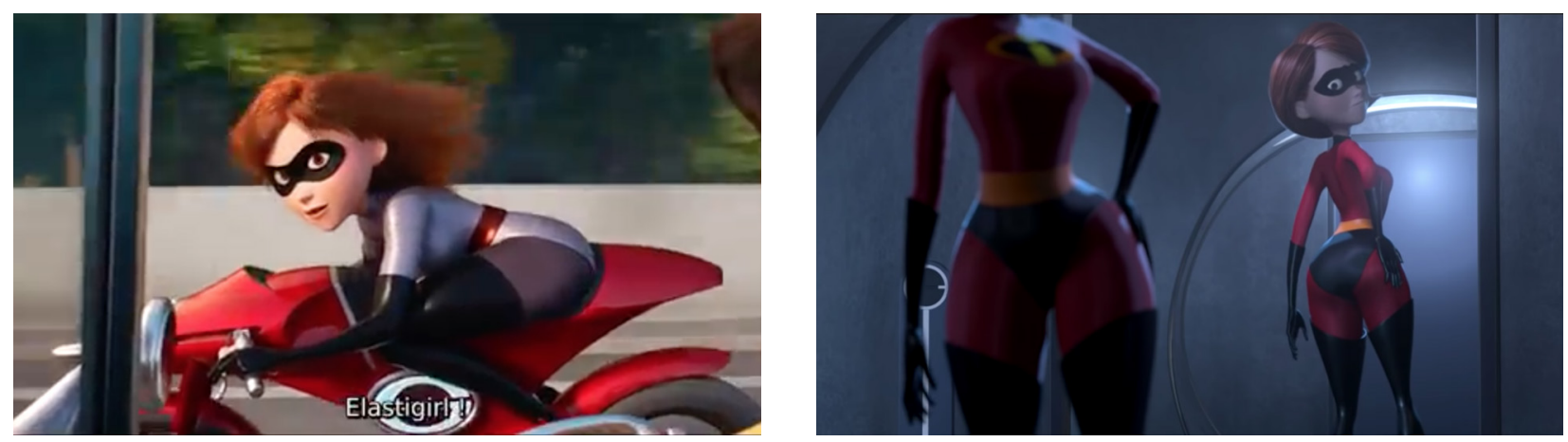

Figure 4. Elastigirl is riding a motorcycle and mirroring herself. 
in The Incredibles 1. Before getting married with Elastigirl, Mr. Incredible said "You know ... you can tell a lot about a woman by the contents of her purse, but maybe that's not what you had in mind. "In my opinion, purse is a symbol of treasure because purse is a small and fashionably designed bag which is used to hold money. Sometimes it also holds keys, cosmetics and other items of daily use. It is also used as a fashion attachment and expresses volumes about the characters of the person carrying it.

The word purse, with its varying designs and colors, implies the proclivity of women in general, which is feminine. However, the contents of the purses do not always include feminine items. It depends on the owner of the purse. The things that women put in their purses depend on their tastes. Not all women put cosmetics in their purses because not all women are feminine. However, not all women who have the same contents of purses have the same tastes and characters. It is because the contents of the purse are like those of wallets. And, cosmetics are compulsory things in this modern era. It means that cosmetics is used to raise their self-confidence, even if the women themselves are not that feminine. Therefore, what is outside and what is inside is sometimes different.

The last sexual objectification being exploited from Elastigirl deals with her behavior and body movements. Her body movements are quite attractive, namely from the way she walks, the way she pauses, to the way her body performs

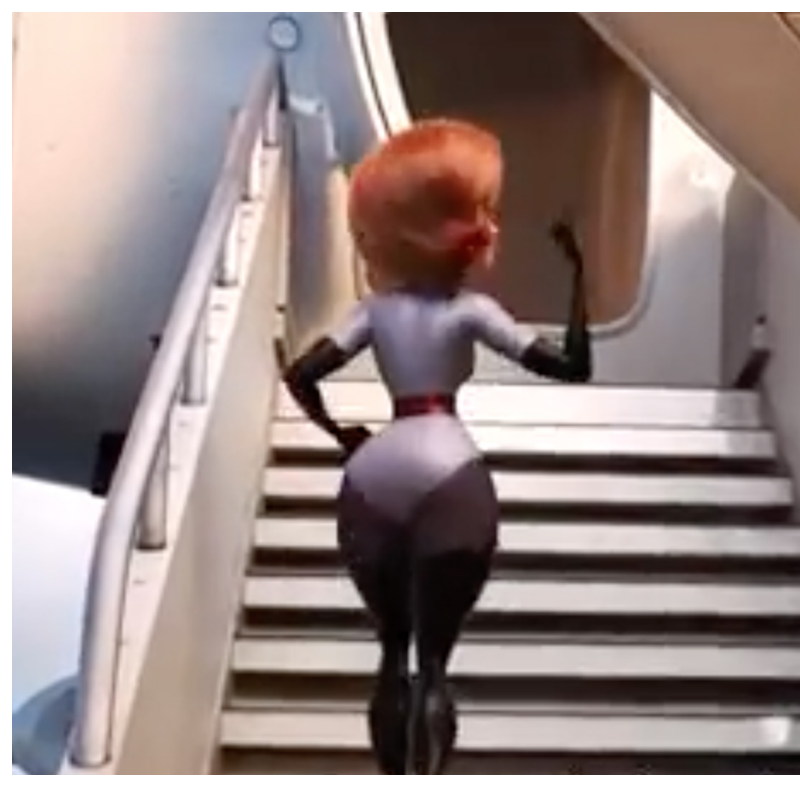

Figure 5. Elastigirl is walking on the stairs. gestures (see Figure 5). Her walk is something that distinguishes men and women. Elastigirl always walks in a graceful manner, while Mr. Incredible walks in a dashing movement. When she is walking, her buttocks are bulging right and left apparently. Both of her thighs are also very close to each other. This kind of walk is described as a feminine walk. When she stops walking, she often puts her left hand above her hip, and this is a very feminine pose. Even though she is a superhero that can fight other strong people, most of her behavior is very feminine. Not only is she feminine, but her walks and pauses also have different meanings. For men, this kind of behavior is very alluring since it is supported with big buttocks and curvy shapes of the body. From her femininity it can be seen that women do not need to be masculine to prevail. They can express their femininity combined with their strong characters, meaning that they can fight tough people, yet could still be independent.

The next body movement that sexually objectifies Elastigirl appears in the scene when both Mr. Incredible and Elastigirl meet each other for the first time in The Incredibles 1. At that moment they have a light argument in a conversation. While Elastigirl is quipping, "Well, I think you need to be more...flexible.", she puts her hand on Mr. Incredible's chest and moves her fingers down to the top of his chest like doing a teasing hand gesture (see Figure 6). That moment turns out to make Mr. Incredible be interested in Elastigirl because that action makes her look more attractive and alluring, especially when we see it from men's eyes. Their meeting ends when Elastigirl leaves Mr. Incredible, and Mr. Incredible lets out a wolf-whistle. However, a wolf-whistle infers negative connotations because it seems like sexual harassment because whistling has been used as men's weapon to tease women. Manalo et al. (2016) defines wolf-whistle as whistle

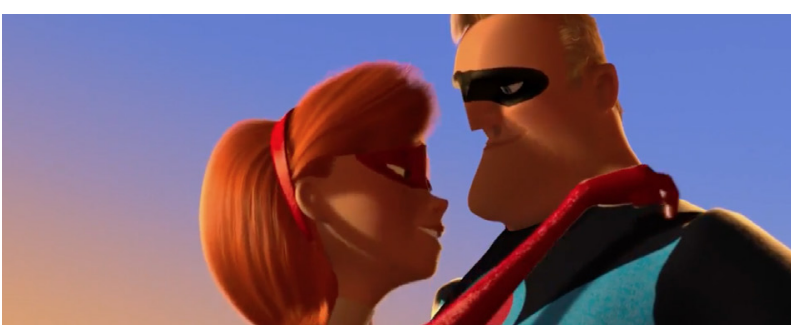

Figure 6. Elastigirl puts her hand on Mr. Incredible's chest at the first time they met. 
that happens when men are playing tones up and down when whistling. This is to symbolize their interest towards women, and this is mostly considered as an offensive act. This whistle is also related to inequality and superiority of men over women. Men use this treatment towards women in order to maintain inequality between the two genders, to show their superiority, and to shape or control women's lives while they fight to gain equality. By doing so, Mr. Incredible is trying to reinforce that inequality towards women, which actually makes Elastigirl uncomfortable.

Another attractive behavior is when she is reclining on her bed while wearing a bathrobe (see Figure 7). Her position is lying on the head of the bed and bending one of her legs. This position makes her look more tempting because it makes her bathrobe slightly upraised, which causes her leg shape visible. This is very alluring for men.

Thus, the objectification of women is still implicitly apparent in both Incredibles movies. Elastigirl is being objectified through her physical features, which makes certain body types look attractive. Moreover, the camera angle often focuses on her certain body parts that are regarded as sexy. Not only limited to her own body and the camera, her behavior also supports the idea that she is sexualized by the moviemakers. Her behavior often can arouse men. The moviemakers might seem to challenge the idea of subjugating women by making them as one of the main superhero characters in this movie series. However, the idea of demeaning women's character is still apparent. According to Mulvey, "the male figure cannot bear the burden of sexual objectification"(1990 [1975]), it implies that he idea of objectification is always attached to the portrayal of women because when men see women, men always have in mind about the sexuality things of women that gives them

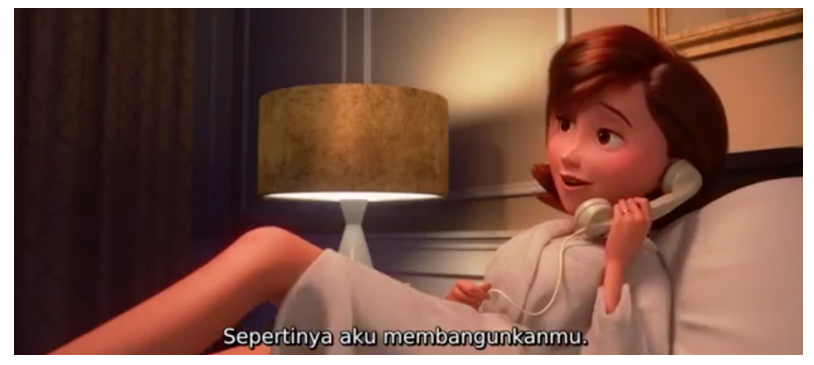

Figure 7. Elastigirl half lies on the bed. a pleasure. Therefore, this movie series do not empower women.

\section{Conclusion}

The alteration of female superheroes in becoming the main characters in the movie industry after decades demonstrates significant progress. However, there are still conventional and negative ideas about men and women that adhere to many efforts in lifting up women's dignity. Because of this, the representation of women empowerment in The Incredibles 1 and 2 is still problematic in two aspects. First, male domination is still apparent through the power division of each main character that makes the roles in becoming superheroes also different. Mr. Incredible has mighty strength compared to Elastigirl, which causes her to have a lesser role that makes her seem weaker than him. Second, Elastigirl's body is oversexualized through her body shape, clothes, behavior, and the way camera angles present her body.

From the way Elastigirl is seen as subordinate to the way she is sexualized, it can be seen that the representation of Elastigirl is a form of pseudo empowerment. Pseudo empowerment in media is when the media capitalizes on the term empowerment to deliver their message, yet, they actually rely on a false conception of feminist ideas. (Gosh, 2015)

It is quite difficult to analyze this topic because one needs to be rigorous in seeing other perspectives from other people, and to see deeper than the superficial message of the movies. It is challenging to find the actual unequal treatment of Elastigirl. Furthermore, this topic is very important in today's era, where there is a lot of "emancipation" for women and there is less "degradation" for them that is actually still apparent if examined more closely. We should be aware of subtle influences that are still apparent in our world to make us not be biased and easily impressed with big things that seem to represent change although not all of them truly promote that change. In this research I did not only see the surface of this movie, like the women's emancipation. Instead, I tried to seek some traditional values that have already been 
addressed by the 'emancipation' of women. Also, I have tried to seek negative portrayals that seem fine at first glance, but actually degrade women. For future research, it might be better if there is audience involvement in this research to make it more reliable. These kinds of superheroes movies, especially The Incredibles 1 and 2, tries to be empowering, but they often fails. There are some aspects in empowerment, but there are still some aspects in oppression that cause the depiction to be disempowering.

\section{References}

Beauvoir, de. (1949). The Second Sex. Uberty. org. Retrieved, November 6, 2018, from https://uberty.org/wp-content/uploads/ 2015/09/1949_simone-de-beauvoir-thesecond-sex.pdf

Burnett, B. (2018). The Incredibles 2 Delivers an Incredible Takedown of Toxic Gender Norms. The Mary Sue. Retrieved, September 15, 2018, from https://www.themarysue.com/ incredibles-2-work-life-balance/

Carolyn, C. (2014). Negotiating the Third wave of Feminism in Wonder woman. ProQuest. Retrieved September 19, 2018, from https://remote-lib.ui.ac.id:2155/docview/ 1471220451 ?pq-origsite $=$ summon

Castillo. V. D. (n.d) The Impact of Globalized Media on Women's Body Image. Academia. Retrieved, December 20, 2018, from, https:// www.academia.edu/6035716/The_Impact_ of_Globalized_Media_on_Women_s_Body_ Image?auto=download

Cellania, M. (2017). Women and Men on Men and Women in Red. Neatorama. Retrieved, December 6, 2018, from https://www. neatorama.com/2017/01/03/Women-andMen-on-Men-and-Women-in-Red/

Conell,R.W.(2005). Masculinities (2 ${ }^{\text {nd }}$ Ed.).Barkeley: University of California Press. Retrieved from, https://genderandmasculinities.files. wordpress.com/2017/02/robert-w-connellmasculinities-second-edition-3.pdf

Dipaolo, M. (2013). Superhero or Super Cliché? Oklahoma Humanities. Retrieved, October 7 ,
2018, from https:/www.okhumanities.org/ websites/ohc/images/magazines/winter_2013/ scarlett_johansson.pdf

Eagly, A. H. (2009). The His and Hers of Prosocial Behavior: An examination of the Social Psychology of Gender. Scribd. Retrieved, March 20 2019, from https://www.scribd. com/document/352427097/The-his-andhers-of-prosocial-behavior-An-examinationof-the-social-psychology-of-gender-pdf

Freeman, K. G. (2018). The Feminist Superheroine: A Critical Evaluation of Patty Jenkins' Wonder Woman. Sam Houston State University. Retrieved, November 2, 2018, from https:// shsu-ir.tdl.org/handle/20.500.11875/2360

Fapohunda, Tinuke. (2009). Women Emancipation for sustainable development in Nigeria: myths, realities and challenges. ResearchGate. Retrieved, march 13 2019, from https://www. researchgate.net/publication/261718410_ Women_Emancipation_for_Sustainable_ Development_In_Nigeria_Myths_Realities_ and_Challenges

Gray, R. (2012). Women wearing red send signals that attract men. The Telegraph. Retrieved, December 6, 2018, from https:// www.telegraph.co.uk/news/science/sciencenews/9105879/Women-wearing-red-sendsignals-that-attract-men.html

Hickey, W. (October 13, 2014). Comic Books Are Still Made By Men, For Men And About Men. Five ThirtyEight. Retrieved, November 1 2018, from https://fivethirtyeight.com/features/ women-in-comic-books/

Kabeer, N. (2002). Resources, Agency, Achievements: Reflections on the Measurement of Women's Empowerment. ResearchGate. Retreived, September 15, 2019, from https://www.researchgate. net/publication/227612461_Resources_ Agency_AchievementsReflections_on_the_ Measurement_of_Women's_Empowerment Karolak, Magdalena (n.d). Between women's Empowerment and Emancipation. Arabian Humanities. Retrieved, 13 march 2019, from https://journals.openedition.org/cy/2108

Kinnunen, J. (2016). Badass Bitches, Damles in 
Distress, or Something in Between? JYX. Retrieved, September 2018, from https:// jyx.jyu.fi

Kulkarni, S. M. (2017). Women Empowerment in $21^{\text {st }}$ Century. Research Gate. Retrieved, January, 3, 2019, from https://www. researchgate.net/publication/317745427_ Women_Empowerment_in_21st_Century

MacPherson, E. E. (2014). Understanding gender power relations, transactional sex and HIV in fishing communities in Southern Malawi. ProQuest. Retrieved, April 22, 2019, from https://livrepository. liverpool.ac.uk/2006663/1/MacPhersonEle_ Feb2014_2002941.pdf

Majhi, G. (2017). Paradox of Gender Equality in Hollywood Superhero Movies. Arts \& Education International Research Journal. Retrieved, October, 7, 2018, from http:// www.imrfournals.in/pdf/MATHS/AEIRJVolume\%204-Issue-2/2.pdf

Manalo, J. G. S., Mercado, I. U., Perez, A. D., Rivera, M. C. C.C, Salangsang, S. A., (2016). Street Harassment As A Determinant of Self-Easteem And Self-Objectification Among Selected Female Students. StopStreetHarrasment. Retrieved, 29 April 2019, from http://www.stopstreetharassment. org/wp-content/uploads/2011/04/ManilaThesis-Street-Harassment.pdf

Mirkin, H. (2009). The Passive Female: The Theory of Patriarchy. American Studies, 25(2), 39-57. Retrieved, March 20, 2019, from https:// journals.ku.edu/amerstud/article/view/ 2566

Mulvey, L. (1990). Visual Pleasure And Narrative Cinema. Composingdigitalmedia. Retrieved, November 1 2018, from http://www. composingdigitalmedia.org/f15_mca/mca_ reads/mulvey.pdf

Neagu, A. (2015). Body image: A theoretical framework. The publishing house of the Romanian academy. Retrieved, December 6, 2018, from http://www.acad.ro/sectii2002/ proceedings Chemistry/doc2015-1/ Art04Neagu.pdf

Red: Symbolic and Cultural Associations. (2019). Object Retrieval. Retrieved, June 13, 2019, from https://www.ucl.ac.uk/museums-static/ objectretrieval/node $/ 277$

Ruane J., Todd J., (2005). "Communal Conflict and Emancipation. The Case of Northern Ireland", in Booth K. (Ed.), Critical Security Studies and World Politics. London: Lynne Rienner Publishers, 237-255.

Ryan, L. (2014). The Three Faces of Motherhood: The Representation of Motherhood and Masculinity in American Films from 1970 to 1980. ProQuest. Retrieved September 19, 2018, from https://remote-lib.ui.ac.id:2155/ docview/1669977682?pq-origsite=summon Tailor, Leena. (2018). The Incredibles 2: Female empowerment and modern families more than fantasy. Stuff. Retrieved September 29, 2017, from https://www.stuff.co.nz/entertainment/ film/104604717/incredibles-2-femaleempowerment-and-modern-families-morethan-fantasty

Trites. R. S. (1997). Waking sleeping beauty: feminist voices in children's novels. Iowa City: University of Iowa Press.

Wingwood \& DiClémente. (2000). Application of the Theory of Gender and Power to Examine HIV-Related Exposures, Risk Factors, and Effective Intervenstions for Women. Citeseerx. Retrieved, March 20, 2019, from http:// citeseerx.ist.psu.edu/viewdoc/download?doi $=10.1 .1 .605 .8742 \& \mathrm{rep}=\mathrm{rep} 1 \& \mathrm{type}=\mathrm{pdf}$

Wright, E. O. (1993). Explanation and Emancipation in Marxism and Feminism. Jstor. Retrieved, October 19, 2018, from https://www.jstor.org/stable/201979 